\title{
First record of Cymatium keenae Beu, 1970 (Mollusca: Ranellidae) from Antofagasta Bay, northern Chile, in connection with El Niño events
}

\author{
Tom Ashton $\cdot$ Jose M. Riascos $\cdot$ Aldo Pacheco
}

Received: 12 May 2007 / Revised: 21 June 2007 / Accepted: 26 June 2007 / Published online: 13 October 2007

(C) Springer-Verlag and AWI 2007

\begin{abstract}
Cymatium (Monoplex) keenae Beu, 1970, the neopolitan triton, is a Ranellidae predator distributed in tropical and subtropical waters. In this study we report this species for the first time in Antofagasta Bay, northern Chile. Adult specimens have been found since June 2003 at depths ranging from 5 to $15 \mathrm{~m}$ in La Rinconada Marine Reserve $\left(23^{\circ} 28^{\prime} 18^{\prime \prime} \mathrm{S}, 70^{\circ} 30^{\prime} 46^{\prime \prime} \mathrm{W}\right)$ in Antofagasta Bay, near a scallop farming facility. The present findings clearly extend the geographic range of $C$. keenae, which previously had been reported from La Paz, Gulf of California (Mexico) to Galápagos Islands (Ecuador) in the SE Pacific. Previous evidence strongly suggests that the intrusion of this tropical immigrant can be related to warm El Niño episodes. We analyze the key role of the oceanographic characteristics of Antofagasta Bay as potential temporal refuge for this species.
\end{abstract}

Keywords ENSO $\cdot$ Geographic distribution $\cdot$ Ranellidae · Antofagasta Bay $\cdot$ Range extension

Communicated by Sven Thatje.

Special Issue: S. Thatje (ed.), Climate variability and El Niño Southern Oscillation: implications for natural coastal resources and management.

\section{T. Ashton}

Gatty Marine Laboratory, School of Biology,

University of St. Andrews, Fife KY168LB, UK

J. M. Riascos $(\bowtie) \cdot$ A. Pacheco Instituto de Investigaciones Oceanológicas,

Universidad de Antofagasta, Av. Angamos 601,

Casilla 170, Antofagasta, Chile

e-mail: josemar.rv@gmail.com

\section{Introduction}

The marine fauna of the Chilean coast is characterized by a complex interaction of tropical, subtropical and subAntarctic elements, a high level of endemism and a close association to climate and oceanographic features, notably sea surface temperature (Castilla 1979; Camus 2001). Particularly the northern and central Chilean coast (between $18^{\circ}$ and $36^{\circ} \mathrm{S}$ ) has been under the disturbing influence of the El Niño-Southern Oscillation (ENSO) since its mid-Holocene development (Moy et al. 2002). Indeed, ENSO now constitutes a critical component for defining the current biogeography of this area (Fernández et al. 2000; Camus 2001).

During warm episodes, warm water masses of low oxygen concentration from oceanic and equatorial regions enter the upwelling zones of Peru and Chile, bringing a variety of tropical immigrants (Arntz et al. 2006). These episodic incursions of tropical species during the warm El Niño (EN) phase of ENSO has been well described (e.g., Díaz and Ortlieb 1993; Paredes et al. 2004; Castilla et al. 2005) and seems to be a common characteristic of those regions in the past (De Vries 1987; Guzmán et al. 2001). However, little is known about how long these temporal invaders thrive after EN conditions and which environmental setting could allow those species to persist. In this study, we report the presence of the tropical gastropod Cymatiun (Monoplex) keenae Beu, 1970 for the first time for Chilean waters. We discuss the role of El Niño as the mechanism explaining the extension of its distributional range and the importance of the oceanographic characteristics of Antofagasta Bay as a refuge for this species under La Niña conditions. 


\section{Methods}

Specimens of Cymatium keenae were collected in February and November 2006 at La Rinconada Marine Reserve $\left(23^{\circ} 28^{\prime} 18^{\prime \prime} \mathrm{S}, 70^{\circ} 30^{\prime} 46^{\prime \prime} \mathrm{W}\right)$, Bay of Antofagasta (Fig. 1). The samples were taken during SCUBA diving expeditions, at a depth ranging between 15 and $5 \mathrm{~m}$ near a scallop farming facility. Two divers covered about $600 \mathrm{~m}^{2}$ area during $2 \mathrm{~h}$ immersion each time. The collected specimens were brought to the laboratory and the shell length (SL: length from the apex to the end of the siphonal canal) was measured to the nearest $0.1 \mathrm{~mm}$.

Local collections of shells in Antofagasta were checked to assess previous occurrences of this species. The taxonomic determination was confirmed by C. Paredes (Laboratorio de Biología y Sistemática de Invertebrados Marinos, Universidad Nacional Mayor de San Marcos, Lima, Perú).

\section{Results and discussion}

Cymatium keenae was found in a soft-bottom community dominated by the scallop Argopecten purpuratus, and the bivalves Transennella pannosa and Tagelus dombeii as well as predatory gastropods, such as the muricids Stramonita chocolata and Xanthochorus cassidiformis. Two adult specimens of $C$. keenae were found in February 2006: a live specimen $(\mathrm{SL}=134.0 \mathrm{~mm})$ and an empty shell $(\mathrm{SL}=142.9 \mathrm{~mm})$. A second live specimen was found in
November $2006(\mathrm{SL}=115.4 \mathrm{~mm})$. One of the live specimens was extremely eroded on the dorsal surface and bore evidence of polychaete infestation, the second and third whorls were broken open and showed signs of internal repair (Fig. 2) while the other one did not show erosion evidence. Review of local collections rendered an additional adult shell ( $\mathrm{SL}=153 \mathrm{~mm}$; Miguel Avendaño private collection, Universidad de Antofagasta). The specimen, without erosion evidence, was collected alive in June 2003 at the La Rinconada, and it was observed among three other adult specimens while performing an annual survey of the scallop bed (M. Avendaño, personal communication).

Species of Cymatium Röding, 1798 are widely distributed marine gastropods belonging to the family Ranellidae and inhabiting warm waters around the world (Skoglund 2002). This genus is known as a predator of wild and farmed bivalve species in a variety of tropical locations (Perron et al. 1985; Urban 2000; Freites et al. 2000). Formerly recognized as Cymatium (M.) parthenopeum keenae (Keen 1971), C. keenae has been recorded as living in warm-water environments in the tropical eastern Pacific with a southern limit in Galápagos at $1^{\circ} \mathrm{S}$ (Keen 1971; Skoglund 2002) although it has been occasionally found in Pucusana $\left(12^{\circ} 28^{\prime} \mathrm{S}\right)$ and Paracas $\left(13^{\circ} 50^{\prime} \mathrm{S}\right)$ at the Peruvian coast (Diaz and Ortlieb 1993). The present findings add an additional $10^{\circ}$ of latitude (about $1,300 \mathrm{~km}$ coastal distance) to the occasional report of $C$. keenae from Pucusana, and $22^{\circ}$ of latitude to the species previous southern limit at the Galápagos Islands.
Fig. 1 Map of La Rinconada, in Antofagasta Bay in northern Chile. Upwelling centres in front of Punta Tetas and Punta Coloso are marked with grey shading. The left graph shows mean sea surface temperature (and standard errors) from 1997 to 2003 obtained from thermistors placed inside and around the bay (adapted from Piñones et al. 2007; Castilla et al. 2002)

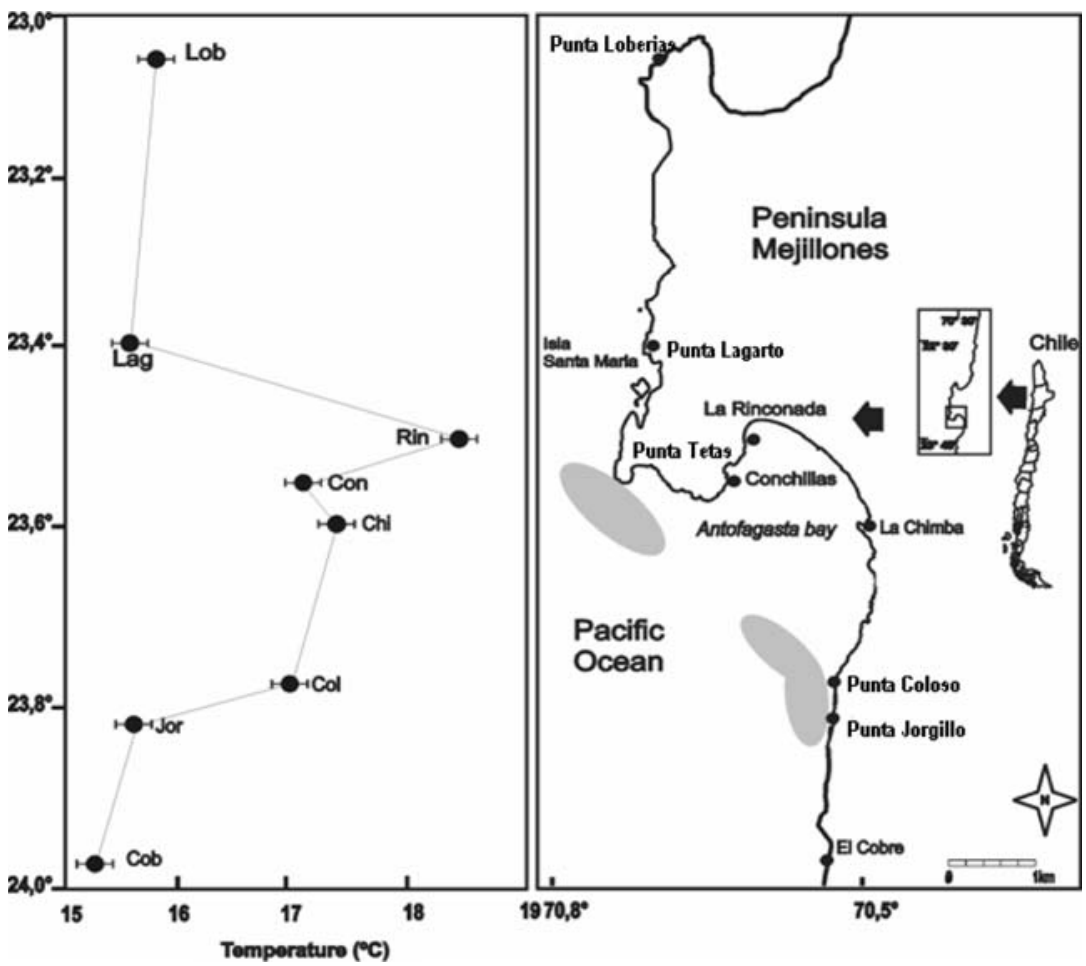




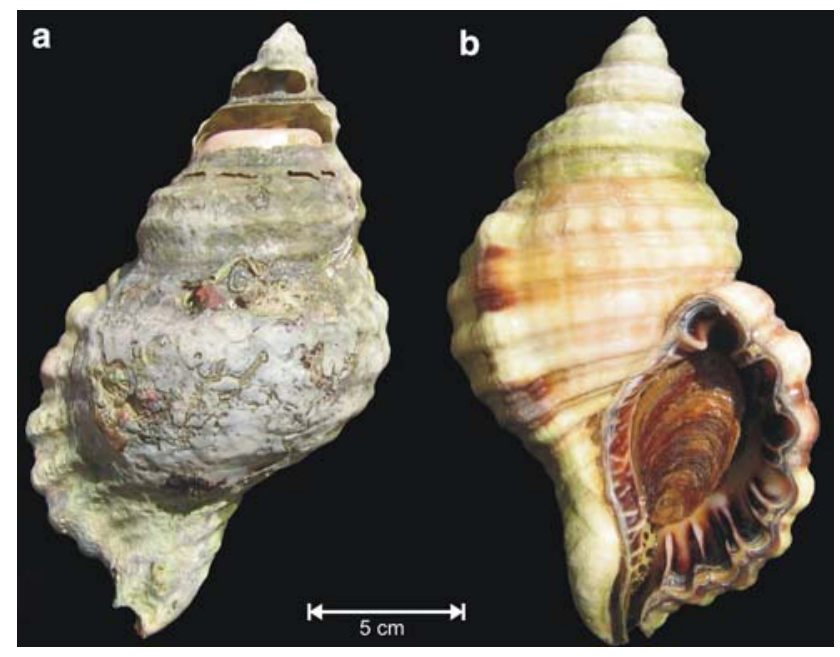

Fig. 2 Cymatium (Monoplex) keenae ( $\mathrm{SL}=134.0 \mathrm{~mm}$ ) collected in Antofagasta Bay in November 2006. a Dorsal view showing erosion and polychaete infestation. b Ventral view without shell damage

The arrival of $C$. keenae in Peruvian waters was attributed to EN, as it was only observed after major EN episodes (Diaz and Ortlieb 1993). During these events, warm water masses from oceanic and equatorial regions enter the upwelling zones, thus transporting meroplanktonic larvae of tropical origin (Arntz et al. 2006). This is most likely the mechanism explaining the arrival of Cymatium keenae to Antofagasta Bay. This species has been shown to have the potential for long-distance trans-oceanic larval dispersal and the possibility to delay metamorphosis in order to facilitate long distance larval transport (Pechenik et al. 1984).

Although these are the first reported findings of this species at La Rinconada, adult $C$. keenae have been found since June 2003. This, and the fact that $C$. keenae is commonly known by local fishermen, who recognize it as "Caracol Perro", indicate that at least some specimens are capable of long term persistence in this bay. Viable populations of the tropical gastropods Aplysia juliana and Linatella weigmanni have been established in Antofagasta Bay after their arrival during EN (Tomicic 1985; Guzmán et al. 1998; Castilla et al. 2005). The question remains if this is the case for $C$. keenae. So far only adult specimens have been found, which would suggest that a reproductive population has not yet formed.

Antofagasta Bay has been shown to play a critical geographical distribution "stepping stone" role for sub-tropical invaders into Chilean waters (Castilla et al. 2005). The oceanographic characteristics of this bay are unique, since it is one of the few bays in Chile facing southward. On the other hand, it is located between two active upwelling centres (Punta Tetas and Punta Coloso, Fig. 1). This creates an "upwelling-shadow" with an almost constant sea water temperature frontal oceanographic structure crossing the mouth. Thus, upwelled waters are retained inside the bay long enough for temperatures to be elevated by several degrees through surface heating. The bay therefore exhibits surface temperatures between $2^{\circ}$ and $4^{\circ}$ higher than surrounding waters, (Castilla et al. 2002; Piñones et al. 2007) allowing it to act as an isolated refuge for occasional arrivals from warmer waters.

Acknowledgments The authors would like to thank Carlos Paredes for providing important assistance regarding the taxonomy of the reported species. Miguel Avendaño is thanked for allowing access to his collection. Marcela Clarke and Ricardo Guiñez provided useful literature. Thanks to Sven Thatje, Martin Thiel, Javier Calcagno, and an anonymous reviewer for providing constructive comments on the manuscript. This study was conducted in the framework of the EU-funded INCO project, "Climate Variability and El Niño-Southern Oscillation: Implications for Natural Coastal Resources and Management" (CENSOR) and Programa Bicentenario de Ciéncia y Tecnología RUE-02. This is CENSOR publication No. 115.

\section{References}

Arntz W, Gallardo V, Gutiérrez D, Isla E, Levin L, Mendo J, Neira C, Rowe GT, Tarazona J, Wolff M (2006) El Niño and similar perturbation effects on the benthos of the Humboldt, California and Benguela current upwelling ecosystems. Adv Geosci 6:243-265

Camus PA (2001) Marine biogeography of continental Chile. Rev Chil Hist Nat 74:587-617

Castilla JC (1979) Características bióticas del Pacífico Sur-Oriental, con especial referencia al sector chileno. Revista de la Comisión Permanente del Pacífico Sur 10:167-182

Castilla JC, Lagos NA, Guiñez R, Largier J (2002) Embayments and nearshore retention of plankton: the Antofagasta Bay and other examples. In: Castilla JC, Largier J (eds) The Oceanography and Ecology of the Near Shore and Bays in Chile. Proceedings of the International Symposium on Linkages and Dynamics of Coastal Systems: Open Coasts and Embayments, Ediciones Universidad Católica de Chile, Santiago, pp 179-203

Castilla JC, Uribe M, Bahamonde N, Clarke M, Desqueyroux-Faúndez R, Kong I, Moyano H, Rozbaczylo N, Santelices B, Valdovinos C, Zavala P (2005) Down under the south eastern Pacific: marine non-indigenous species in Chile. Biol Invasions 7:213-232

De Vries TJ (1987) A review of geological evidence for ancient El Niño activity in Peru. J Geophys Res 92:14471-14479

Diaz A, Ortlieb L (1993) El fenómeno "El Niño" y los moluscos de la costa Peruana. Bulletin de 1 Institut Françoise de études andines 22:159-177

Fernández M, Jaramillo E, Marquet PA, Moreno CA, Navarrete SA, Ojeda FP, Valdovinos C, Vásquez J (2000) Diversity, dynamics and biogeography of Chilean benthic nearshore ecosystems: an overview and guidelines for conservation. Rev Chil Hist Nat 73:797-830

Freites L, Himmelman J, Lodeiros CJ (2000) Impact of predation by gastropods and crabs recruiting onto culture enclosures on the survival of the scallop Euvola ziczac (L.) in suspended culture. J Exp Mar Biol Ecol 224:297-303

Guzmán N, Díaz A, Ortlieb L, Clarke M (2001) TAMAs, ocurrencia episódica de moluscos tropicales en el norte de Chile y el evento El Niño. In: Tarazona J, Arntz WE, Castillo de Maruenda E (eds) El Niño en America Latina: Impactos Biológicos y Sociales. Consejo Nacional de Ciencia y Tecnología, Lima, Perú, pp 385-393 
Guzmán N, Saá S, Ortlieb L (1998) Descriptive catalogue of nearshore molluscs (Gastropoda and Pelecypoda) from Antofagasta area, $23^{\circ} \mathrm{S}$ (Chile). Estud Oceanol (Chile) 17:17-86

Keen AM (1971) Sea Shells of Tropical West America. Marine Mollusks from Baja California to Perú. 2nd Edn, Stanford University Press, Stanford

Moy CM, Seltzer GO, Rodbell DT, Anderson DM (2002) Variability of El Niño/Southern Oscillation activity at millennial timescales during the Holocene epoch. Nature 420:162-165

Paredes C, Cardoso F, Tarazona J (2004) Distribución temporal de moluscos y crustáceos tropicales en la Provincia Peruana y su relación con los eventos El Niño. Rev Per Biol 11:213-218

Pechenik JA, Scheltema RS, Eyster LS (1984) Growth stasis and limited shell calcification in larvae of Cymatium parthenopeum during trans-atlantic transport. Science 224:1097-1099
Perron FE, Heslinga GA, Fagolimul JO (1985) The gastropod Cymatium muricinum, a predator on juvenile tridacnid clams. Aquaculture 48:211-221

Piñones A, Castilla JC, Guiñez R, Largier JL (2007) Nearshore surface temperatures in Antofagasta Bay (Chile) and adjacent upwelling centers. Ciencias Marinas 33:37-48

Skoglund C (2002) Panamic province molluscan literature. Additions and changes from 1971 through 2001. III Gastropoda. The Festivus 33(Suppl):1-286

Tomicic JJ (1985) Efectos del fenómeno El Niño 1982-83 en las comunidades de la Península de Mejillones. Invest Pesq (Chile) 32:209-213

Urban HJ (2000) Culture potential of the pearl oyster (Pinctada imbricata) from the Caribbean: II. Spat collection, and growth and mortality in culture systems. Aquaculture 189:375-388 